\title{
The Value of International Criminal Justice: How Much International Criminal Justice Can the World Afford?
}

\author{
Ernst Hirsch Ballin \\ University Professor, Tilburg University, Tilburg, The Netherlands; Professor, \\ Human Rights Law, University of Amsterdam, Amsterdam, The Netherlands
}

\begin{abstract}
International criminal justice, and in particular the ICc, has been overburdened by the unrestrained idealism underlying the ambitions inscribed in its fundaments. However, the resulting acts of legal development have not been without value. On the contrary, it is only when idealism sharpens our view on reality that progress can be achieved. Striving to gradually strengthen international criminal justice is therefore worthwhile. Our best bet is to seek to understand where shortcomings in the existing system are grist to the mill for cynicism and to look for opportunities to make international criminal justice more credible in the eyes of victim populations. The question of how much criminal justice the world can afford is the wrong question to ask. Rather, we should be asking whether the international community, if it is still concerned about establishing trust and peace among nations, can afford to do away with international criminal justice.
\end{abstract}

\section{Keywords}

international criminal justice - International Criminal Court (ICC) - human rights law

The question 'How much international criminal justice can the world afford?', sometimes raised with a financial thrust, reflects a change in the mindset about international criminal justice. In 1998, the unforgettable Antonio Cassese (1937-2011) wrote an article outlining why, in the case of war crimes

(C) ERNST HIRSCH BALLIN, 2018 | DOI:10.1163/15718123-01806003

This is an open access article distributed under the terms of the prevailing CC-BY-NC license at the time of publication. 
and crimes against humanity, justice is better than revenge, forgetting or an amnesty. ${ }^{1}$ Cassese has since died, while another protagonist of international criminal justice, M. Cherif Bassiouni, passed away in the summer of 2017. The question discussed here may also, therefore, serve as a wake-up call for younger generations to avoid a situation in which growing cynicism about the international rule of law and international human rights, and diminishing support for multilateralism, undermine the project of international criminal justice, which is still in a sensitive initial phase of life.

An assessment of the value of international criminal justice can the world afford?' concerns international criminal justice in general, which is at present delivered by the International Criminal Court (ICC), with an open, comprehensive task, and by a patchwork of hybrid and other specialized tribunals. ${ }^{2}$ There are various angles from which international criminal justice can be assessed, including its costs, the efficiency of the ICC's operations and its effects within societies which were torn apart by internal warfare and horrendous crimes. However, the starting point for any assessment here is whether or not criminal justice should be an integral part of the international legal order.

The idea of international criminal justice as an element of the international legal order is relatively new, and in any event does not pre-date the first steps in the process of redefining international law as no longer being exclusively dependent on the consent of each international sovereign subject. At first, the idea of trying war criminals and perpetrators of crimes against humanity was seen - also in the minds of international actors - as confirmation that they had fought and won a just war. After the First World War, for example, it was planned to put the deposed Kaiser Wilhelm II and goo others on trial ${ }^{3}$ (these efforts were abandoned when the Netherlands refused to extradite the former Kaiser, while the other indictments were transferred to a German court, which ultimately tried twelve individuals, half of whom were acquitted). After the Second World War, too, trials were held in Nuremberg and Tokyo, this time with much more force, and based on irresistibly justifying evidence.

1 A. Cassese, 'Reflections on International Criminal Justice', 61(1) The Modern Law Review (1998) 1-11.

2 Some of the most pressing questions concerning the ICC are discussed in R.H. Steinberg (ed.), Contemporary Issues Facing the International Criminal Court (Brill Nijhoff, Leiden, 2016).

3 Articles $227-230$ of the Treaty of Versailles. 
Nevertheless, the idea of criminal justice as a permanent component of the international legal structure is still relatively recent. Since its beginnings in 1993, the Netherlands has been involved in promoting international criminal justice and the idea of accepting rules designed to put an end to impunity and to oblige states to try or extradite even high-ranking suspects were responsible for by establishing international tribunals and courts. ${ }^{4}$ But even though it culminated in the acceptance of the Rome Statute of the ICC, the movement towards international criminal justice was not a one-way street. Instead, there were complications along the way, such as the UK Minister of Justice's undermining of the House of Lords' ruling in the Pinochet case, and the highest court in the Netherlands' interpretation of the non-retroactivity principle in the Bouterse case, such that it covered not only the requirement for punishability at the time the crime was committed, but also the jurisdiction. ${ }^{5}$ According to Kai Ambos, with whom I concur, this latter view is inconsistent with the idea behind the nullum crimen principle. ${ }^{6}$ The most important setback, however, was of a political nature because although the United States, China and the Russian Federation accepted the establishment of the International Criminal Tribunal for the former Yugoslavia (ICTY) and the International Criminal Tribunal for Rwanda (ICTR), they were reluctant to accept the ICC as a body where their own service personnel and even leaders could face prosecution. Since then, feelings of living in a hostile world have dominated politics in both the United States and Russia.

Here we are confronted with a fundamental problem: the fostering of trust among people and nations requires institutions to be built on foundations that are themselves based on an intuitive trust. Imbalances of power and - in the case of terrorism - the weaponizing of existential fears undermine the conditions needed to create trust-promoting institutions. Although international terrorism has been an additional reason for reinforcement of international cooperation in law enforcement, populist responses dismiss the importance

4 See the speech delivered by the Netherlands Minister of Justice at the Conference of Ministers of Justice on the occasion of the $100^{\text {th }}$ anniversary of the Hague Conference on International Private Law', Peace Palace, The Hague, 19 May 1993, and the continuous Dutch support for the establishment of the ICTY, for example, and later for the ICTR Appeals Chamber and the ICC in The Hague.

5 Cf. E.M.H. Hirsch Ballin, 'De zaak Pinochet: commentaar op de uitspraak van het House of Lords van 24 maart 1999', Ars Aequi (2000) 481-489, 488; Bouterse case, 18 September 2001, Hoge Raad (Court of Cassation of the Netherlands), ECLI:NL:HR:2001:AB1471.

6 K. Ambos, Internationales Strafrecht: Strafanwendungsrecht - Völkerstrafrecht-Europäisches Strafrecht-Rechtshilfe (C.H. Beck, Munich, 2018) p. 6. 
of international cooperation and suggest that only strong nation-states can effectively respond to these threats. Diminishing support for international criminal justice is also part of an increasingly sceptical - if not cynical - approach to human rights and international enforcement of human rights. Under the influence of the 'clash of civilizations' ideology, the protection of human rights is arrogantly claimed as an achievement of 'the West' not accepted by and, therefore, not suitable to be exported to other parts of the world. This attitude contradicts the very purpose and nature of human rights.

This does not mean, however, that international criminal justice is succumbing to enfeeblement within twenty years after its initial success. Institutions can be sufficiently resilient to overcome downward political conjunctures. The ICC and the various specialized tribunals have so far managed to do precisely that. They administer justice, and each judgment they issue is tremendously important for the individuals and groups involved in the history of the case. Apparent political expediency should not distract from the importance of these facts.

It is above all, however, the changed international political climate that is turning the cards against international criminal justice. Encouraged by the bias of targeted political communications, many political leaders are preferring to 'stand up for their own people' and are now more interested in defeating their enemies and destroying the latter's power bases than in achieving justice for victims in a sophisticated judicial process. To the extent that these leaders are interested in peaceful settlement, their interest is often more in the results of negotiations than in justice being seen to be done. That explains why African leaders, while sincerely striving for peace in Sudan, opposed the arrest of President Bashir that was intended to result in his being tried before the ICC. Article 27 of the Rome Statute states that 'official capacity as a Head of State or Government, a member of a Government or parliament, an elected representative or a government official shall in no case exempt a person from criminal responsibility under this Statute'. Under Security Council (sc) Resolution $1593,{ }^{7}$ which referred the situation in Darfur to the ICC, Sudan is theoretically obliged to arrest its own president. However, Article 98 appears to confirm that other states have to respect President Bashir's immunity as a head of state. ${ }^{8}$ Meanwhile, Article 16 of the Rome Statute allows an investigation or prosecution to be deferred in the interest of conflict resolution:

7 Resolution 1593 of the United Nations Security Council (s/RES/1593 (2005)).

8 D. Akande, 'The Legal Nature of Security Council Referrals to the ICC and its Impact on Al Bashir's Immunities', 7 Journal of International Criminal Justice (2009) 333-352. 
No investigation or prosecution may be commenced or proceeded with under this Statute for a period of 12 months after the Security Council, in a resolution adopted under Chapter VII of the Charter of the United Nations, has requested the Court to that effect; that request may be renewed by the Council under the same conditions. ${ }^{9}$

This indictment of an acting head of state, which some considered to be bizarre, together with the feeling that African situations were disproportionately often the object of investigations and prosecutions, provoked some African countries to renounce their membership of the state parties to the Rome Statute. ${ }^{10}$ The contention that targeting African situations reflected post-colonial prejudices was especially harmful, ${ }^{11}$ the most convincing counterargument is that complaints from African victims were - as, indeed, they should be - precisely the reason why the Court became involved in the first place.

\section{A Mission Impossible?}

It is now time to consider how best to reverse the negative trend in political support for international criminal justice. Is a different approach possible? But before discussing this question, we should ask ourselves whether the expectations at the time the Court was established went beyond what it could reasonably hope to achieve. My view is that the enormous ambitions expressed at the launch and presenting of the ICC go at least some way to explaining the crisis it currently finds itself in. Three elements can be identified in this respect.

$9 \quad$ N. White, International Conflict and Security Law (Elgar Advanced Introductions, Edward Elgar, Cheltenham, 2014) p. 120.

10 On the 'threatened African exodus from the ICC', see, for instance, the recent paper by C.R. Rossi, 'Hauntings, Hegemony, and the Threatened African Exodus from the International Criminal Court', 40(2) Human Rights Quarterly (2018) 369-405, also available at SSRN: https://ssrn.com/abstract=2969130, accessed 27 October 2017. On the relationship between the ICC and the African continent, see also, for example, J.-B. Jeangène Vilmer, 'The African Union and the International Criminal Court: Counteracting the Crisis', 92(6) International Affairs (2016) 1319-1342; K. Mills, "Bashir is Dividing Us”: Africa and the International Criminal Court', 34(2) Human Rights Quarterly (2012) 404-447; V.O. Nmehielle (ed.), Africa and the Future of International Criminal Justice (Eleven International, The Hague, 2012).

11 See R. Schuerch, The International Criminal Court at the Mercy of Powerful States - An Assessment of the Neo-Colonialism Claim Made by African Stakeholders (Asser Press/ Springer, The Hague, 2017). 
But while, if taken together, these elements may suggest disillusionment, they should not necessarily be seen as the end of the story:

The ICC was established with a grandiose ambition. In other words, according to the preamble to the Rome Statute, the Court's ambition is to put an end to impunity for the perpetrators of the most serious crimes of concern to the international community. Article 5 distinguishes four such crimes:
1. The crime of genocide;
2. Crimes against humanity;
3. War crimes;
4. The crime of aggression.

Given the wide definitions of these crimes in the Rome Statute, and the many armed conflicts and examples of systematic repression in the world, tens of thousands of suspects could qualify to be tried either by domestic courts or, "complementary to national criminal jurisdictions" (Article 1 of the Rome Statute), by the ICC or specialized tribunals. Some news reports made headlines by stating that more than $\$ 900$ had been spent on the ICc by the time the first suspect (Thomas Lubanga from Congo) was convicted. ${ }^{12}$ At the same time, however, it was rightly observed that:

The ICc budget has to pay for staff salaries, building rental, global travel, intensive investigations in often hostile terrain, translators, for the defence teams, for legal aid for defendants and victims and so on. The court registry - the administrative heart of the tribunal - pays most of these bills, which explains why it takes up around half of the budget. So the impression, on paper, that the bureaucrats are getting a disproportionate slice of the cake, is misleading. ${ }^{13}$

Actually, both sides of the above equation miss the point: the ICC is not designed to try large groups of people, and the apparent majesty of its premises and equipment is largely explained by the complex nature of state-of-the-art criminal proceedings. If measured against the standard of putting an end

\footnotetext{
12 J. Silverman, 'Ten Years, \$9oom, One Verdict: Does the ICC Cost Too Much?', BBC News Magazine, 14 March 2012, http://www.bbc.com/news/magazine-17351946, accessed 27 October 2017.

13 Ibid.
} 
to (or at least approaching the end of) impunity, the ICC cannot be seen as having succeeded. Moreover, other grave injustices, such as crimes of corruption relating to international terrorism, ${ }^{14}$ or the displacement and undermining of vulnerable populations' living conditions, ${ }^{15}$ do not fall within the ICC's competence.

The quantitative disappointment felt is thus a consequence of the overreaching ambitions vested in the ICC, and this disappointment is aggravated by an understandable feeling among victims and their communities that some bad people have got away with the benefit of the doubt. This, however, is characteristic of conscientious criminal judgments and of punishment that can hardly be seen as retribution for the often inconceivable nature of atrocities committed. In that sense, there is an unavoidable mismatch between the law and the crime, a subject raised by David Luban when reflecting on Hannah Arendt's account of the Eichmann trial. ${ }^{16}$

The establishment of the ICC was part of the hope felt in the late-twentieth century that it would be possible to establish a worldwide rule of law and gradually constitutionalizing international law. According to Erika de Wet, 'The constitutionalization of the international legal order through the recognition of a human-rights-based hierarchy ... is first and foremost a European phenomenon, the broader impact of which is still uncertain.17 International human rights treaties containing mechanisms for oversight, also at the request of individuals and collectivities, appeared to emulate global law enforcement, whereas the 'duty to protect' justified replacing oppressive regimes by democracies with international support, and 'preferably' with a mandate from the sc. International criminal justice appeared in this way to have become a new cornerstone of 'governing the world'. The re-emergence of power politics and the

14 L.I. Shelley, Dirty Entanglements: Corruption, Crime, and Terrorism (Cambridge University Press, New York, 2014).

15 S. Sassen, Expulsions - Brutality and Complexity in the Global Economy (Belknap Press, Cambridge, MA, 2014).

16 According to David Luban, this is one of 'the biggest questions international criminal law must answer'. See D.J. Luban, 'Hannah Arendt as a Theorist of International Criminal Law', 11(3) International Criminal Law Review (2011) 621-641, Georgetown Public Law Research Paper No. 11-30, p. 30, available at SSRN: https://ssrn.com/abstract=1797780, accessed 27 October 2017; also in M. Goldoni and C. McCorkindale (eds.), Hannah Arendt and the Law (Routledge, London, 2017) pp. 425-445, p. 445.

17 E. de Wet, '(Implicit) judicial favoring of human rights over United Nations Security Council sanctions: a manifestation of international constitutionalism?', in F. Fabbrini and V.C. Jackson (eds.), Constitutionalism Across Borders in the Struggle against Terrorism (Edward Elgar, Cheltenham, 2016) pp. 35-51, p. 51. 
rise of inward-oriented politics have since, however, thwarted these ambitions. 'The idea of governing the world is becoming yesterday's dream..$^{18}$ A certain tension between hegemony in international relations and the constitutionalization of international law is unavoidable and bearable within certain limits of self-restraint. ${ }^{19}$ Yet in recent years, diminishing support for multilateralism resulting from populist, 'own nation first' politics - has further reduced the opportunities for international criminal justice to serve as the watchdog of the international rule of law.

In accordance with the notions of international rule of law, the ICC and its judges are expected to act independently (Articles 40 and 42). This expectation contrasts sharply with the dynamics of international power-broking in and around the SC and summits. The independence of the ICC and its judges is, of course, essential, and also means they can remain outside the gravitational fields that define their 'elbow room'. Although this is in principle the same as in domestic constitutional systems, national judiciaries usually have a base of socially and culturally founded authority, if necessary against political powers. As a result, the deterrent effect of international criminal justice - as we can see every day in several parts of Africa, in Syria and in Myanmar - has fallen sharply below the expectation voiced in the preamble to the Rome Statute that international criminal justice would 'contribute to the prevention of such crimes'. This situation has been aggravated by differences in constitutional and political cultures.

\section{Redefined Expectations}

The conclusion of the above observations must surely be that international criminal justice, and in particular the ICC, has been overburdened by the unrestrained idealism underlying the ambitions inscribed in its fundaments. ${ }^{20}$ Although the enthusiasm at the Rome Conference was almost irresistible among those present, including representatives of non-governmental organizations

18 M. Mazower, Governing the World: The History of an Idea (Penguin Books, London, 2012) p. 427.

19 See on struggles over hegemony G.W. Anderson, 'Constitutionalism as critical project: the epistemological challenge to politics', in S. Gill and A. C. Cutler (eds.), New Constitutionalism and World Order (Cambridge University Press, Cambridge, 2014) pp. 281-294 (289).

20 For a skeptical account of the workings of the ICC, see S. Nouwen, 'Justifying justice', in J. Crawford and M. Koskenniemi (eds.), The Cambridge Companion to International Law (Cambridge University Press, Cambridge, 2012) pp. 327-351. 
that supported the establishment of the Court, that enthusiasm has been seen to provide an insufficient basis, with the ratification of the Statute being unable to change the underlying realities. It is a typical legal drafters' fallacy to think that as soon as expectations are carved into normative stone, reality will follow suit. In the case, however, of international criminal justice, even more so than in established constitutional and legal forms of life, legal normativity and social reality interact at a much slower pace than decision-makers anticipate.

That does not mean that these acts of legal development are without value. On the contrary, it is only when idealism sharpens our view on reality that progress can be achieved. In this way, striving to gradually strengthen international criminal justice is worthwhile. However, ambitious idealism has to stay close to the varieties of societal life, which are mainly an unorganized, autonomous process. While public institutions are certainly important in this context, they should not feel they need to be in full control: rather, they must be available wherever trust is broken and has to be restored. Gradual progress towards more effective protection of human rights is a desirable development, albeit one with ups and downs, backlashes, and moments of progress. This is where the availability of institutions for international criminal justice can play a role, especially in situations where people are seeking to restore a civilized order. Citizens in formerly fragile states can benefit from legal protection through acknowledgement of their rights as citizens. But encouraging a culture of the rule of law is not enough. Think, for instance, of the ordeal of the 800,00o Rohingya people who have fled from their home country that does not recognize their citizenship. Although the ICc has not yet been asked to deal with this situation, it could be another possible case to be submitted to the Court. Refugees are often fleeing violence that amounts to crimes in the sense of the Rome Statute. Under the Sustainable Development Goals (sDGs), setting up reliable rule-of-law institutions can be part of the process of investing in development. uN Secretary-General António Guterres recently said that safe migration cannot be limited to the global elite and stressed the need to do more to respond to the challenges of migration. Refugees, internally displaced people and migrants are not the problem; the problem lies in conflict, persecution and hopeless poverty. ${ }^{21}$

There are many more situations in which the Court would be an appropriate complementary mechanism, without overstepping its capacities. 'Postconflict situations' are often characterized by high numbers of people having been victimized in an unrestricted internal war. While such situations require

21 António Guterres, Address to the General Assembly, 19 September 2017, https://www.un .org/sg/en/content/sg/speeches/2017-09-19/sgs-ga-address, accessed 9 January 2018. 
the restoration of justice, they usually lack judicial institutions with sufficient capacities and authority among population groups that have been set against each other. ${ }^{22}$

And much more has still to be done. At an early stage, the international courts and tribunals recognized the importance of protecting victims against permanent victimization, and the need to assist them in their role as witnesses. For many years, this subject has been one of the Dutch priorities in research especially at Intervict (Tilburg University's Institute for Victimology) - and also in practice, through the extra contributions made available to assist witnesses. The effects of hearing victims as witnesses go far beyond a specific prosecution in contributing to the recognition of deprived population groups' suffering. In this way, the multiplier effect of prosecutions means that even if the number of criminal cases at the ICC remains limited, the fact that these prosecutions have taken place can still be very important in the eyes of affected population groups.

It is consequently important to adapt the law enforcement methods of international criminal justice in such a way that more and more perpetrators of crimes against humanity are forced to face judges. That is not the same as establishing an overarching international criminal justice system in The Hague the institutional interpretation of complementarity. There is no need to revise the Rome Statute at this point, but the political acceptance and support with respect to a situation-based, functional complementarity needs to be strengthened, for good reason. In this vein, local methods of reconciliation, like those applied in South Africa and Rwanda, are supplemented by the judicial processes that only an international court can provide.

4

Conclusion

Our best approach is to seek to understand where shortcomings in the existing system arouse cynicism and to look for opportunities to make international criminal justice more credible in the eyes of victim populations. To this end, the various courts and tribunals should not operate in an environment that is unnecessarily remote from the societies concerned. On the one hand, this remoteness may admittedly contribute to impartiality and calmness in the proceedings. On the other hand, however, differing views on what constitutes appropriate punishment (the ICC cannot issue a death penalty, for example)

22 S.L. Woodward, The Ideology of Failed States - Why Intervention Fails (Cambridge University Press, Cambridge, 2017); White, supra note 9, pp. 119-121. 
and seemingly comfortable detention conditions could alienate people from international criminal justice. The value of hybrid courts and tribunals is partly to be found in the balance they manage to achieve between the extremes of remoteness from and involvement in underlying tensions.

Notwithstanding the 'harsh reality' with which the ICC has been confronted, ${ }^{23}$ I agree with Armin von Bogdandy and Ingo Venzke, ${ }^{24}$ who believe that the fact that so many states have endorsed international adjudication can - and must - be seen as a confirmation of democratic values. The politically legitimate establishment of independent international courts demonstrates trust in the basic values of democracies abiding by the law, including human rights law. Therefore, what we can expect from honest international adjudication, including international criminal justice, is, in the first place, a highly visible confirmation of these values.

The importance of the courts and tribunals for international criminal justice must be seen firstly in their availability. Wherever post-conflict situations or situations in which the rule of law is being restored can benefit from processes in which justice can be done (and be seen to be done), the parties involved in the transition or the SC should have the opportunity to avail themselves of these judicial bodies' organization and expertise. And that, in turn, is also the most important argument for having the ICC as a court standing ready.

There are also highly practical reasons for ensuring these institutions' availability. Perpetrators who flee the country where they committed the crimes cannot always be extradited to their country of origin. In these cases, an international, hybrid or foreign criminal court has to step in. And sometimes it is more acceptable for both sides in a contested post-war situation to have an impartial international court dealing with the crimes committed. With respect to certain crimes, especially those directed against women, such as where rape is used as a method of warfare, disrespectful local attitudes adversely impact on the ability of local courts to handle these cases. In such cases, international courts are consequently better positioned to do justice.

The rights of women and children are part of the international human rights framework and are intended to protect the most vulnerable members of many societies. International human rights protection must not fade away as a side-effect of neglected enforcement. Indeed, international criminal justice is an indispensable part of human rights since other enforcement mechanisms,

\footnotetext{
23 Tjitske Lingsma, All Rise - The High Ambitions of the International Criminal Court and the Harsh Reality (Ipso Facto, Utrecht, 2017).

24 A. von Bogdandy and Ingo Venzke, In wessen Namen? Internationale Gerichte in Zeiten globalen Regierens (Suhrkamp, Berlin, 2014) pp. 280-281.
} 
such as judiciaries and oversight committees, are effective only within the context of more or less orderly constitutional settings. ${ }^{25}$ More generally, the victims' perspective ${ }^{26}$ requires an effective complementarity of 'local' and international prosecutions. ${ }^{27}$ Here, the innovative approaches in the practice of the ICC may serve to encourage the introduction of adequate procedures for victim participation in hybrid and national jurisdictions. ${ }^{28}$

For the reasons outlined above, any further loss of momentum in international criminal justice would represent a dramatic setback in the development of the international rule of law. That does not mean that everything in its current modus operandi should remain unchanged. Reviewing the procedures for hearing witnesses and bringing them more in line with the continental or civil law approach rather than the common law approach could, for example, be helpful. ${ }^{29}$ Given that impunity is a lasting burden for societies, victims and their relatives, peace and reconciliation require justice to be seen to be done. But sufficient consensus on the need to prosecute is also needed. Referral by a certain number of states could therefore serve as an alternative starting point. While referrals by the SC are often a desirable and more workable starting point than the prosecutor's own initiative, being exclusively dependent on the SC would place each of the permanent members, including the most powerful nations, in an undesirable gatekeepers' position. An acceptable alternative would be to grant the SC the right to halt proceedings at the ICC in the interests

25 This function of international criminal justice is quite often overlooked or left out from overviews of human rights law. It does, however, surface at several instances in D. Shelton (ed.), The Oxford Handbook of International Human Rights Law (Oxford University Press, Oxford, 2013).

26 On victim participants' views on the ICC and its operations, see, for instance, Human Rights Center, Uc Berkeley School of Law, The Victims' Court? A Study of 622 Victim Participants at the International Criminal Court, 2015, https://www.law.berkeley.edu/wp-con tent/uploads/2015/04/VP_report_2015_final_full2.pdf, accessed 27 October 2017.

27 See also Luke Moffett, 'Realising Justice for Victims before the International Criminal Court', 6 ICD Brief (September 2014), http://www.internationalcrimesdatabase.org/up load/documents/20140916T170017-ICD\%2oBrief\%20-\%2oMoffett.pdf, accessed 27 October 2017 , in which it is stated on p. 11: 'To more effectively achieve justice for victims of international crimes, it requires states to domestically deliver it and for the ICC to be a court of last resort. As such, a more victim-oriented approach to complementarity is required, where states are encouraged and monitored to provide redress to victims locally'. See K. Tibori-Szabó and M. Hirst (eds.), Victim Participation in International Criminal Justice - Practitioners' Guide (Asser Press/Springer, The Hague, 2017).

29 The differences in practice are discussed in L. Carter and F. Pocar (eds.), International Criminal Procedure - The Interface of Civil Law and Common Law Legal Systems (Edward Elgar, Cheltenham, 2013). 
of promoting peaceful international relations. The effect of the veto power in the SC would thus be inverted. ${ }^{30}$

Lastly, the questions I have raised here are not about only a specialized branch of criminal law, but also about the intertwinement of international criminal law and human rights law, and international law in general, in a fragmented world order. Torture and other infringements of human dignity abound, with human rights currently under pressure in many parts of the world. ${ }^{31}$ The urgent need to deploy a range of efforts, including international criminal justice, in fighting this situation is evident. Inevitably, international criminal justice is focused on suspects and perpetrators. Moving in the direction of constitutionalism in international law, this perspective should be complemented by other perspectives, i.e. that of the victims, of the community within the supposed criminal acts took place, and of the larger community that lives under the same legal order. From all these viewpoints, human rights like the right to protection of life and personal dignity belong to the constitutional framework.

The route we should pursue is to restore and strengthen trust in human rights in borderline situations rather than going in the diametrically opposed direction, as commonly seen at present, of a post-multilateral, free-for-all international system. 'How much criminal justice the world can afford?' is therefore the wrong question to ask. Instead, what we should be asking is whether the international community, if it is still concerned about establishing trust and peace among nations, can afford to do away with international criminal justice.

30 This idea is a variation on the reverse qualified majority requirement in Article 7 of the Treaty on Stability, Coordination and Governance in the Economic and Monetary Union.

31 Cf. D. Luban, 'Treatment of prisoners and torture', in M. Düwell, J. Braarvig et al., The Cambridge Handbook of Human Dignity: Interdisciplinary Perspectives (Cambridge University Press, Cambridge, 2014) pp. 446-453. 